\title{
Kinetic Spectrophotometric Determination of Morphine in Pharmaceutical Samples
}

\author{
MOHSEN KEYVANFARD ${ }^{1}$ and FAEZE AMRI ${ }^{2}$ \\ 'Department of Chemistry, Majlesi Branch, Islamic Azad University, Isfahan, Iran. \\ ${ }^{2}$ Department of Chemistry, University of Payame Nour, Isfahan Branch, Iran. \\ ${ }^{*}$ Corresponding author E-mail keyvan45638@yahoo.com
}

http://dx.doi.org/10.13005/ojc/300444

(Received: September 30, 2014; Accepted: October 15, 2014)

\begin{abstract}
A new, sensitive, simple, inexpensive and fast kinetic spectrophotometric method was developed for the determination of trace amounts of morphine over the range of $12-60 \mathrm{ng} / \mathrm{mL}$. The method is based on the catalytic effect of morphine on the reaction of bromate and methylene bluein acidic media is reported. The reaction was monitored spectrophotometrically by $60 \mathrm{ng} / \mathrm{ml}$ measuring the decrease in absorbance of methylene blue at $665 \mathrm{~nm}$ with a fixed-time $0.5-2.5 \mathrm{~min}$ from initiation of the reaction. The detection limit is $0.8 \mathrm{ng} / \mathrm{mL}$ and relative standard deviation of 12 and $52 \mathrm{ng} / \mathrm{mLmorphine}$ for 6 replicate measurements was 1.50 and $0.87 \%$ respectively. The method 12 and $52 \mathrm{ng} / \mathrm{ml}$ was applied to the determination of morphine inpharmaceutical samples $\%$ respectively.
\end{abstract}

Key words: Morphine, Kinetic, Determination, Methylene blueCatalytic.

\section{INTRODUCTION}

Morphine extracted from the plant papaver somniferum ${ }^{1}$ Morphine (MO) is a useful drug in relieving patients of severe pain, but it's excessive or habitual use frequently causes toxic symptoms ${ }^{2}$ Morphine is the primary constituent of opium. It is the most important drug of the opiates group $^{3}$. The use of morphine as an analgesic in pre-term newborns is very common, due to the many painful procedures and stressful circumstances they undergo $\mathrm{O}^{4,24,25}$ anditusedforthetherapy of reduce to severe pain, especially aftersurgical procedures. Toxic effects of morphine usage can be harmful for
human.Morphine is a useful drug but it's excessive orhabitual use frequently is harmful.

Different methods have been reported for detecting morphine. These include: spectrophotometry, ${ }^{5}$, immuno chromatography ${ }^{7}$, potentiometry, ${ }^{8}$, simultaneous voltammetric and amperometric ${ }^{10}$, gc-mass ${ }^{1,11,26}$, cyclicvoltametry and amperometry $^{12}$, cyclicvoltametry ${ }^{13,14}$, sequential injection analysis ${ }^{4}$,chemiluminescence ${ }^{15}$, kinetic potentiometric ${ }^{9}$, high performance liquid chromatography ${ }^{16-19}$, gas chromatography ${ }^{20}$, capillary electrophoresis ${ }^{21}$, ion mobility spectrometry ${ }^{22,23}$. These methods are efficient, but 
require expensive instrument and are expensive and many of them have needing time to complete the determination. Some of this methods have high limit of detection. Therefore, the need for a sensitive, simple, fast and selective method for the determination of morphine is obvious. In this paper, we developed and validated a rapid, sensitive kinetic spectrophotometric method for the determination of morphine based on its catalytic effect on the reaction of bromate and methylene blue in acidic media.Morphine sulfate $5 \mathrm{H}_{2} \mathrm{O}$ has the following structure ( Figure 1).

\section{EXPERIMENTAL}

\section{Reagents and Apparatus}

Doubly distilled water and analytical reagent grade chemicals were used during all of the experimental studies.Methylene bluesolution $3.1 \times 10^{-4} \mathrm{M}$ was prepared by dissolving $0.0100 \mathrm{~g}$ of the compound (Merck) in water and solution was diluted to the mark in a $100 \mathrm{~mL}$ volumetric flask.Bromate stock solution 0.25 Mwas prepared by dissolving $4.1752 \mathrm{~g}$ of potassium bromate $(\mathrm{M}=167)$ in water and diluting to $100 \mathrm{~mL}$ in volumetric flask.Standard stock morphine solution 10 $\mu \mathrm{g} / \mathrm{mL}$ was prepared by dissolving $0.0013 \mathrm{~g}$ of morphine sulfate $5 \mathrm{H}_{2} \mathrm{O}(\mathrm{M}=758.83)$ in water and diluting to $100 \mathrm{~mL}$ in volumetric flask. The working solutions were prepared by serial dilution of it in water. Sulfuric acid solution was prepared by appropriate dilution of concentrated sulfuric acid (Merck).All glassware were cleaned with detergent solution, rinsed with tap water, soaked in dilute $\mathrm{HNO}_{3}$ solution $(2 \% \mathrm{~V} / \mathrm{V})$, rinsed with water and dried.

\section{Apparatus}

Absorption spectra were recorded with a CECIL model 7500 spectrophotometer with a $1.0 \mathrm{~cm}$ quartz cell. A model pharmacia biotech (Novaspec II)spectrophotometer with $1.0 \mathrm{~cm}$ glass cuvettes was used to measure the absorbance at a fixed wavelength of at665 nm. A thermostat water bath (Gallen Kamp Griffin, BGL240 V) was used to keep the reaction temperature at $30^{\circ} \mathrm{C} \pm 0.1$. A stopwatch was used for recording the reaction times.

Recommended Procedure. All the solutions and distilled water were kept in a thermostated water batch at $30{ }^{\circ} \mathrm{C} \pm 0.1$ for $20 \mathrm{~min}$ for equilibration before starting the experiment. An aliquot of the solution containing120-600ng/ $\mathrm{mLmorphine} \mathrm{was} \mathrm{transferred} \mathrm{into} \mathrm{a} 10 \mathrm{~mL}$ volumetric flask, and then 2.0mL0.5 $\mathrm{M} \mathrm{H}_{2} \mathrm{SO}_{4}, 1.0 \mathrm{~mL} 0.1 \mu \mathrm{g} / \mathrm{mL}$ morphine and $0.8 \mathrm{~mL} 3.1 \times 10^{-4} \mathrm{Mmethyleneblue} \mathrm{were}$ added to the flask. The solution was diluted to $7.0 \mathrm{~mL}$ with water. Then, $1.0 \mathrm{~mL} 0.25 \mathrm{M}$ bromate was added and the solution was diluted to the mark with water. The solution was mixed and a portion of the solution was transferred to the spectrophotometer cell. The reaction was followed by measuring the decrease in absorbance of the solution against water at 665 $\mathrm{nm}$ for $0.5-2.5 \mathrm{~min}$ from initiation of the reaction. This signal (sample signal) was labeled as $\Delta \mathrm{A}_{\mathrm{s}}$. The same procedure was repeated without addition of morphine solution and the signal(blank signal) was labeled as $\Delta \mathrm{A}_{\mathrm{b}}$. Time was measured just after the addition oflast drop of bromate solution. Analytical signal was deference between sample signal and blank signal $\left(\Delta \mathrm{A}_{\mathrm{s}-} \Delta \mathrm{A}_{\mathrm{b}}\right)$.

\section{RESULTS AND DISCUSSION}

Methylene blue is a dye that can be oxidized with strong oxidizing agents. We found that trace amount of morphine have a catalytic effect on the this reaction. Therefore, by measuring thedecrease in absorbance of methylene bluefor a fixed time of $0.5-2.5 \mathrm{~min}$ initiation of the reaction, the morphine contents in the sample can be measured. There are many methods, such as fixed-time, initial rate, rate constant and variable time methods for measuring the kinetic species. Among these, the fixed-time method is the most conventional and simplest, involving the measurement of "A at 665

Table 1: Effect of foreign substances on the determination of $60 \mathrm{ng} / \mathrm{mL}$ morphine

\begin{tabular}{|c|c|}
\hline Tolerance limitw $_{\text {ion }} / \mathbf{w}_{\text {morphine }}$ & Foreign ion \\
\hline $\mathrm{Na}^{+}, \mathrm{K}^{+}$ & 1000 \\
\hline Glocose & 700 \\
\hline Sucrose & 500 \\
\hline Urea, $\mathrm{NH}_{4}^{+}$ & 200 \\
\hline Citric acid, $\mathrm{Zn}^{2+}, \mathrm{Ag}^{+}, \mathrm{Fe}^{3+}$ & 100 \\
\hline $\mathrm{I}^{-}, \mathrm{IO}^{3-}$ & 10 \\
\hline 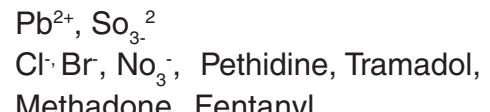 & 5 \\
\hline
\end{tabular}


$\mathrm{nm}$ ( Figure 2).Methylene blue has the following structure ( Figure3).

\section{Influence of Variables}

In order to take full advantage of the procedure, the reagent concentrations must be optimized. The effect of acid concentration, methylene blue concentration, bromate concentration and temperature on the analytical signal was studied.

The effect of sulfuric acid concentration on the analytical signal was studied in the range of $0.07-0.13 \mathrm{M}$ ( Figure4). The results show that the analytical signal increases with increasing sulfuric acid concentration up to $0.10 \mathrm{M}$ and decreases at higher con-centrations. Therefore, a sulfuric acid concentration of $0.10 \mathrm{M}$ was selected for further study.

The influence of methylene blue concentration on the analytical signal was studied in the concentration range of $1.2 \times 10^{-5}-4.3 \times 10^{-5} \mathrm{M}$ ( Figure5).The results show that the analytical signal increases with increasing methylene blue concentration up to $2.5 \times 10^{-5} \mathrm{M}$ and decreases at higher concentrations. Therefore, a methylene blue concentration of $2.5 \times 10^{-5}$ Mwas selected for further study.

Figure 6 shows the effect of the bromate concentration on the analytical signal for the range of $1.5 \times 10^{-2}-3.5 \times 10^{-2} \mathrm{M}$. This analytical signal increases with increasing bromate concentration

Table 2: Determination of free morphine in synthetic samples

\begin{tabular}{lcccc}
\hline Sample & Morphine added & Morphine found & RSD ( $\mathbf{n = 4 )}$ & Recovery\% \\
\hline \multirow{2}{*}{ Ampoule } & 60.0 & $62.1 \pm 0.3$ & 103.5 & 0.48 \\
& 12.0 & $11.2 \pm 0.1$ & 93.3 & 0.89 \\
& 28.0 & $26.8 \pm 0.3$ & 95.7 & 1.12 \\
& 44.0 & $46.5 \pm 0.3$ & 105.7 & 0.64 \\
\hline
\end{tabular}

Table 3: Comparison of some methods for determination of morphine with proposed method

\begin{tabular}{llll}
\hline Method & LDR/(ng/ml) & DL/(ng/ml) & Reference no \\
\hline Kinetic spectrophotometry & $48-76$ & 1.8 & propesedmethod \\
Kinetic spectrophotometry & $1500-13500$ & - & 6 \\
lon mobility spectrometry & - & 60 & 16 \\
High performance liquid chromatography & $171.18-57060$ & 28.5 & 21 \\
Gc-mass & $250-2000$ & 250 & 4 \\
Gc-mass & $50-2000$ & 20 & 15 \\
Kinetic potentiometry & $110-2900$ & 41 & 12 \\
Immunochromatography & - & 10 & 11 \\
High performance liquid chromatography & $3.5-1000.0$ & 3.5 & 14 \\
Cyclic voltammetry & $5.98-329.20$ & 2.39 & 18 \\
Gc-mass & $5-500$ & 1.0 & 17 \\
Exploiting sequential injection analysis & $100-2500$ & 23 & 5 \\
Simultaneous voltammetric and amperometric & $570.6-285300$ & 28.53 & 8 \\
Cyclic voltammetry & $57.06-11412$ & 5.7 & 19 \\
Kinetic spectrophotometry & $570.6-285300$ & 28.53 & 8 \\
\hline
\end{tabular}




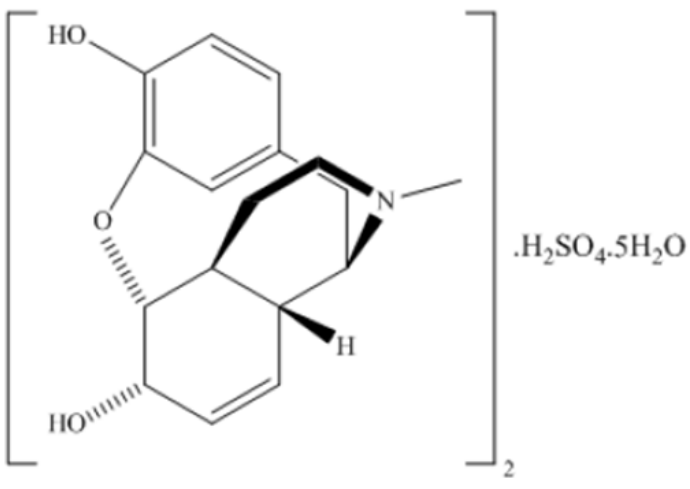

Fig. 1: Structure of morphine sulfate $5 \mathrm{H}_{2} \mathrm{O}$

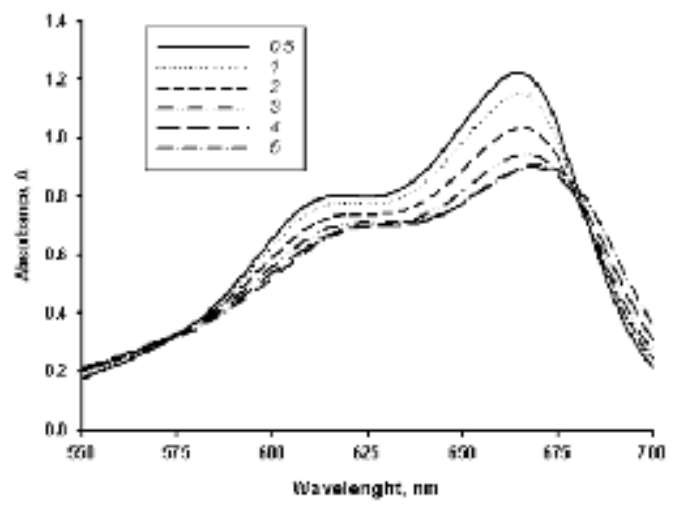

up to $2.5 \times 10^{-2} \mathrm{M}$ and decreases at higher concentrations. Therefore, a final concentration of $2.5 \times 10^{-2} \mathrm{M}$ of bromate was selected as the optimum concentration.

The effect of ionic strength on the analytical signal was studied. The results showed that, as the ionic strength increases, analytical signal slightly increases.

The effect of the temperature on the analytical signal was studied in the range $20-38^{\circ} \mathrm{C}$ with the optimum of the reagents concentrations. The results showed that, as the temperature

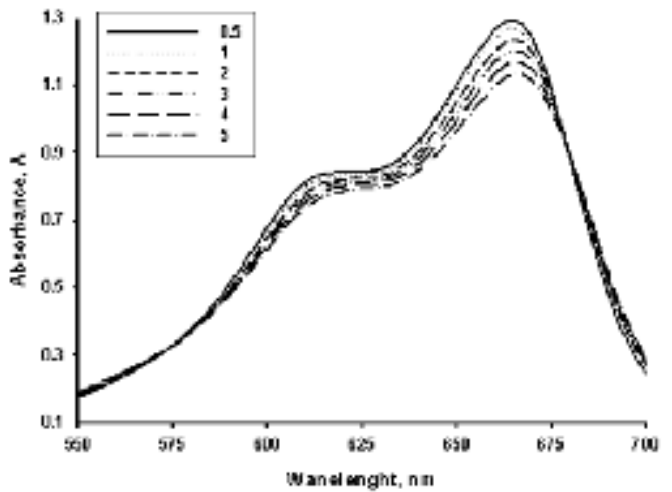

Fig. 2: Absorption spectrum for the morphinemethylene blue $-\mathrm{BrO}_{3}$ " system with time. Conditions: $\mathrm{H}_{2} \mathrm{SO}_{4}$ , $0.10 \mathrm{M}$; methylene blue, $2.5 \times 10^{\prime 5} \mathrm{M}$; $\mathrm{BrO}_{3}{ }^{\prime 0.025} \mathrm{M}$; temperature, $30{ }^{\circ} \mathrm{C}$; interval time for each scan, 0.5 and2.5from initiation of the reaction. a- in presence of $20 \mathrm{ng} / \mathrm{mL}$ of morphineb-in absence of morphine<smiles></smiles>

Fig. 3: Structure of methylene blue

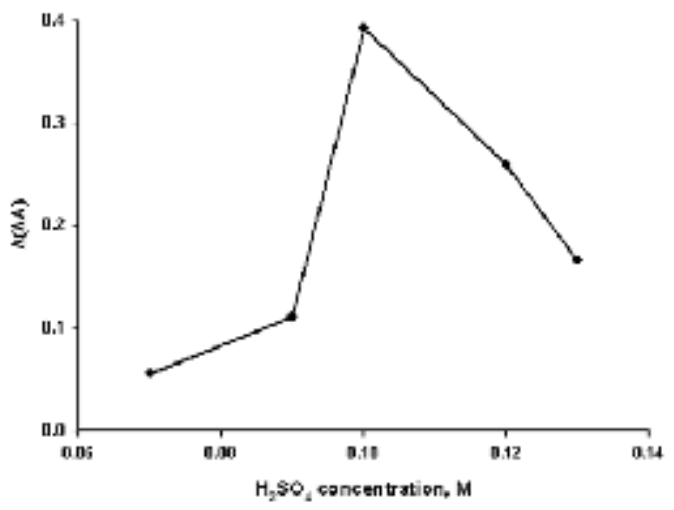

Fig. 4: Effect of $\mathrm{H}_{2} \mathrm{SO}_{4}$ concentration on the analytical signal. Conditions methylene blue3.1×10"5 $\mathrm{M}$; $\mathrm{BrO}_{3}{ } 0.025 \mathrm{M}$; temperature, $30{ }^{\circ} \mathrm{C}$ and time of $3.5 \mathrm{~min}$ from initiation of the reaction 


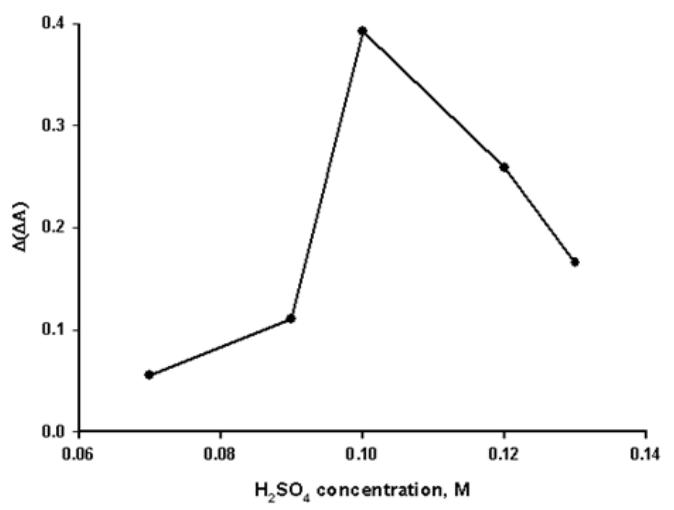

Fig. 5: Effect of methylene blue concentration(MB) on the analytical signal. Conditions: $\mathrm{H}_{2} \mathrm{SO}_{4}$, $0.10 \mathrm{M}$; $\mathrm{BrO}_{3}^{-}, 0.025 \mathrm{M}$, temperature, $30^{\circ} \mathrm{C}$; and time of $3.5 \mathrm{~min}$ from initiation of the reaction

increases up to $30^{\circ} \mathrm{C}$, the analytical signal increases, whereas higher temperature values decrease the analytical signal $\left(\Delta \mathrm{A}=\Delta \mathrm{A}_{\mathrm{s}}-\Delta \mathrm{A}_{\mathrm{b}}\right)$. Therefore, $30^{\circ} \mathrm{C}$ was selected for further study.

Calibration Graph. Precision and Limit of Detection. Calibration graph were obtained using the fixedtime method. This method was applied to the change in absorbance over an interval of $0.5-2.5 \mathrm{~min}$ from initiation of the reaction because it provided the best regression and sensitivity. The equation of the calibration graph is $\Delta \mathrm{A}=0.0145 \mathrm{C}_{\text {morphine }}+$ $0.2827(\mathrm{n}=7, \mathrm{r}=0.999)$ in the range of $12-60 \mathrm{ng} / \mathrm{mL}$. The calibration graph was constructed by plotted of $\Delta \mathrm{A}_{\mathrm{s}}$ at a fixed -time method versus morphine concentration. The limit of detection (Defined as $\mathrm{DL}=3 \mathrm{~S}_{\mathrm{b}} / \mathrm{m}$, where $\mathrm{DL}, \mathrm{S}_{\mathrm{b}}$ and $\mathrm{m}$ are limit of detection, standard deviation of the blank signal and slope of the calibration graph, respectively) is equal to $1.8 \mathrm{ng} / \mathrm{mL}$ morphine. The relative standard deviation for five replicate determination of 12 and $52 \mathrm{ng} /$ mLmorphine was 1.50 and $0.87 \%$ respectively.

Interference Study. In order to assess the application of the proposed method to synthetic samples, the effect of various ions and substances on the determination of $20 \mathrm{ng} / \mathrm{mL}$ morphine was studied. The tolerance limit was defined as the concentration of a added ions causing a relative

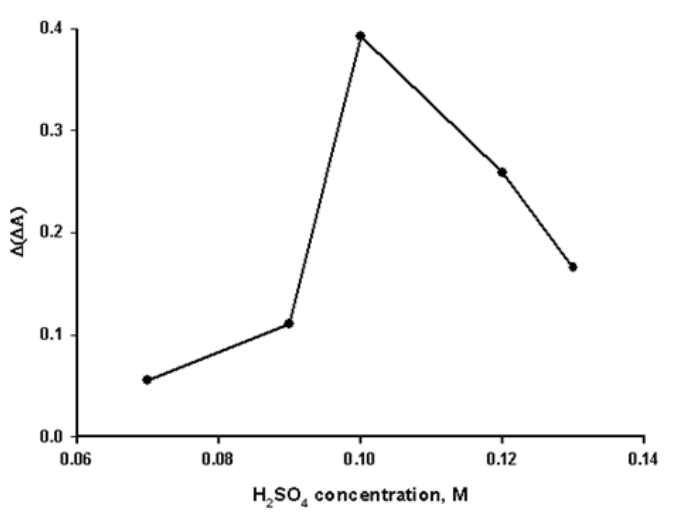

Fig. 6: Influence of $\mathrm{BrO}_{3}$ " concentration on the analytical signal. Conditions: $\mathrm{H}_{2} \mathrm{SO}_{4} 0.10 \mathrm{M}$; methylene blue $2.5 \times 10^{15} \mathrm{M}$, temperature, $30{ }^{\circ} \mathrm{C}$ and time of $\mathbf{3 . 5} \mathrm{min}$ from initiation of the reaction.

error less than $3 \%$ the results are summarized in Table 1.

\section{Preparation of Real Samples}

In order to evaluate the applicability of the proposed method to analysis of real sample the method was applied to pharmaceutical samples (ampoule) for determination of morphine.The results obtained by the proposed method are given in Table 2.

\section{CONCLUSION}

The kinetic-spectrophotometric method developed for the determination of morphine is inexpensive, uses readily available reagents, allows rapid determination at low operating costs and shows simplicity,good precisionandaccuracy compared to other kinetic procedures as shown in Table 3. With this method, it is possible to determine morphine at levels as low as $12 \mathrm{ng} / \mathrm{mL}$.

\section{ACKNOWLEDGMENTS}

The author are thankful to the Islamic Azad University-Majlesi Branch and University of Payame Nour-Isfahan Branch for the supportof this work. 


\section{REFERENCES}

1. Van Thuyne, W., Van Eenoo, P., Delbeke, F.T. Chromatography B. 2003, 785, 245-251.

2. Sakaia, G. ,Ogataa, K., Udab, T., Miuraa, T. and Yamazoe, T., Sensors and Actuators B. Chemical 1998 , 49, 5-12.

3. Idris, A.M., Alnajjar, A.O, Talenta 2008,77, 522-526.

4. Cherry, D.A., Gourlay, G.K., Agents Actions 1994, 42, 173-174.

5. Malovanovic, G.A., Sekhtea, M.A., Mikrochimica 1984, 84, 477-483.

6. Sheibani, A., Shishehbore, M.R., Mirparizi, E., SpectrochimicaActa Part A 2010,77, 535538.

7. Lyubavina, I.A., Zinchenko, A.A., Lapenkov, M.I., Nikolaeva, T.L. 2005, 31, 99-103.

8. Hassan, S.S.M., El-Naby, E.H., Elnemma, E.M., Russian Journal of Bioorganic Chemistry 1996, 124, 55-62.

9. Pejic, N., Anic, S., Mijatovic, M. Milenkovic, S., Ciric, J., Grozdic, T.,Nauka, tehnika,bezbednost 2003,13, 67-74.

10. Xu, F., Gao, M., Wang, L., Zhou, T., Jin, L., Jin, J., Talanta 2002, 58, 427-432.

11. Melent'ev, A. B., Journal of Analytical Chemistry 2003, 59, 566-570.

12. Pournaghi-Azar, M.H., Saadatirad, A., Electroanalytical chemistry2008, 624, 293298.

13. Ganjali, M.R., Norouzi, P., Dinarvand, R., Farrokhi, R., Moosavi-movahedi, A.A., Materials Science and Engineering C.2008, 28, 1311-1318.

14. Li, F., Song, J., Shan, C., Gao, D., Xu, X., Niu, L., Biosensors and Bioelectronics2010, 25, 1408-1413.

15. Francisa, P.S., Adcock, J.L., Costin, J.,
Purcell, S.D., Pfeffer, F.M., Barnett, N.,J. Pharm. Biomed. Anal.2008, 48, 508-518.

16. Rop, P. P., Grimaldi, F., Burle, J., De Saint Leger, M. N., Viala, A., Journal of Chromatography. B.1994, 661, 245-253.

17. Domnguez-Ramrez, A. M., Cortes-Arroyo, A., y de la PeLa, M. H., Aoki-Maki, K., Medina Lopez, J. R., Ros-CastaLeda, C., LopezMunoz, F.J., Journal of Pharmaceutical and Biomedical Analysis 2006, 40, 1172-1178.

18. Sato, K., Chiba, T., Chiba, R., Satou, S., Tanaka, S., ANALYTICAL SCIENCES.2001,17, 1041-1043.

19. Berga, T., Lundanes, E., Chritophersen, A.S., Strand, D.H., J.Chromatogr. B.2009, 877, 421-432.

20. Hofmann, U., Seefried, S., Schweizer, E., Ebner, T., Mikus, G., Eichelbaum, M., J.Chromatogr. B.1999, 727, 81-88.

21. Mi, J.Q., Zhang, X.X., Chang, W.B., . J. Immunoassay Immunochem2004,25, 5770.

22. McCooeye, M.A., Ells, B., Barnett, D.A., Purves, R.W., uevremont, R., . Journal of Analytical Toxicology2001, 25, 81-87.

23. Khyamian, T., Tabrizchi, M., Jafari, M.T., .TalantaQuantitative analysis of morphine and noscapine using corona discharge ion mobility spectrometry with ammonia reagent gas2006, 69, 795-799.

24 .Breivik, H., ActaAnaesthesiolScand 2001,45, 1059-1066.

25 .Lyun, A.M., Nespeca, M.K., Opheim, K.E., Slattery, J.T., Anesth. Analg1993, 77, 695701.

26. Javidnia, K., Miri, R., Miri, D., IJMS2006, 31, 213-215. 